Kułyk, P., \& Augustowski, Ł. (2017). Convergence of health expenditure in EU 12 and V4 states. Copernican Journal of Finance \& Accounting, 6(2), 33-43. http://dx.doi.org/10.12775/CJFA.2017.009

\author{
PIOTR KUKYK* \\ University of Zielona Góra \\ KuKasz Augustowski** \\ University of Zielona Góra
}

\title{
CONVERGENCE OF HEALTH EXPENDITURE IN EU 12 AND V4 STATES
}

Keywords: convergence, European Union, V4 states, government expenditure, healthcare.

\section{J E L Classification: F0, I1.}

\begin{abstract}
The subject of this paper is an attempt to assess the level of convergence of government health spending in the European Union countries. The ever-increasing level of life expectancy, demographic changes, including the aging of society in many European countries, and the development of medical technologies are a growing challenge for modern nations. The similarities in the changes taking place in the EU states lead to considering whether there are similar transformations in health spending? Ensuring access to primary healthcare is one of the tasks of the welfare state and it can be assumed to be a public good. Accepting these reasons, the authors set out to investigate the phenomenon of sigma and beta unconditional convergence for the level of government spending on health care in the EU countries. The answer to the question has been sought: does participation in the EU leads to convergence in government spending on he-
\end{abstract}

Date of submission: August 8, 2017; date of acceptance: September 18, 2017.

* Contact information: p.kulyk@wez.uz.zgora.pl, University of Zielona Góra, Faculty of Economics and Management, Chair of International Economics, Podgórna 50 (budynek A-0), 65-246 Zielona Góra, Poland, phone: +48 683282555.

** Contact information: l.augustowski@wez.uz.zgora.pl, University of Zielona Góra, Faculty of Economics and Management, Chair of International Economics, Podgórna 50 (budynek A-0), 65-246 Zielona Góra, Poland, phone: +48 683282555. 
alth care? The study uses selected dispersion measures for sigma convergence calculations and econometric modelling for beta convergence.

\section{IIINTRODUCTION}

Health care expenditure is one of the most important types of state expenditure. Due to the prolongation of life expectancy, the aging process of European societies, the use of modern medical technologies, their importance is constantly growing. The similarity in these phenomena makes it possible to suppose that changes in health policy, especially in health care expenditure, will show some form of convergence in EU countries. Previous research results show the disproportion in this spending in EU countries, and the presented results of research on convergence are not clear. Due to the spatial and temporal extent of analyses, the presentations of many authors' conclusions differ. The authors sought to answer the question whether the presence of states in the European Union leads to convergence in government spending on health care. The discussed issue may be useful for further reflections on the issue of integration in the European Union. The dependent variable in the study was the level of government spending on health care to GDP, as a result of the disaggregation of total government spending on individual sub-spending. The analysis uses statistical and econometric methods.

\section{RESEARCH ON THE CONVERGENCE OF HEALTH CARE EXPENDITURE IN EU COUNTRIES - PRESENT FINDINGS}

The method of convergence analysis is known and applied to a wide spectrum of research not only in economic sciences, especially with regard to changes in economic growth. Initially, convergence analysis was mainly used to study the occurrence of real convergence between countries or regions. For this purpose, the main variable was real GDP per capita. Such research has been conducted by many authors for different groups of states. Over time, the idea of convergence began to be used to assess the transformations of other areas of economic life, and, as Kusideł points out (2013, p. 9), it does not necessarily refer only to GDP per capita analysis. An example of this is the use of convergence in the analysis of health care expenditure in the EU countries (Hnatyszyn-Dzikowska \& Wyszkowska, 2015, p. 127-135), in the analysis of government expenditure of the Euro zone states and Poland (Kułyk \& Augustowski, 
2016, pp. 247-255), when analysing expenditures on the agricultural sector (Czyżewski \& Kułyk, 2009, pp. 41-51) or studying convergence in food consumption (Wan, 2005, pp. 90-102). In the literature of the subject relatively often it is possible to find studies using this method in research on the size of state expenditure and their spatial convergence. Such research are also occurring as regards the convergence of national health spending, although their numbers are relatively small. Referring to this area of convergence assessment, on the one hand, in most countries the aging process of societies is observed, albeit with varying dynamics, which is linked to the growing demand for care for the elderly. The existence of a European model of the welfare state (though in various forms) leads to posing a hypothesis of convergence in the amount of health care expenditure. On the other hand, European societies differ in their social and family structures, as well as in the characteristics of welfare states. (Zaidi et al., 2017, p. 139). It is also pointed out that unequal patterns of health care expenditure, which are a clear feature of late capitalist society (Lau, Fung \& Pugalis, 2014, p. 137). The measurement of convergence of health expenditures alone, as suggested by Strzelecka (2011, p. 214), is justified by the provision of information on the degree and convergence of countries in the case of budget allocations to health care. Due to the small number of studies conducted in this field, there are no clear results indicating the convergence (or lack thereof) of health expenditure. Additional diagnostic problems and the comparability of the results are based on the method adopted by the authors of various papers, the time range included in the econometric models and finally the selection of states. Each of these factors can affect the final outcome of convergence indicators. Long-term studies demonstrated the convergence of health expenditure (sigma and beta) for 1960-1995 for the EU15 countries (Nixon, 1999, pp. 1-37; Nixon, 2000, pp. 1-27). In the Hitiris study (1997, pp. 1-6), however, the occurrence of such convergence for the period 1960-1991 for the EU12 countries was undermined. An analysis of the various EU Member States in the period 1992-2004 confirmed the existence of convergence, although the tendency for convergence was not maintained throughout the analysed time range. The main period of convergence was 2002-2004 for sigma convergence in the EU 15. (Kerem, Püss, Viies \& Maldre 2008, pp. 29-43). The studies on the convergence of health expenditures were also made for 19 OECD countries (1972-2006) where convergence was demonstrated, although differences in US and Norway were indicated (Panopoulou \& Pantelidis, 2012, pp. 3909-3920). Relatively new research on the convergence of health expenditure were also 
conducted, among the others, in Africa (Odhiambo, Wambug \& Kiriti-Ng'ang'a, 2015, pp. 185-205) or in China (Zhang, Zhang, Wu, Xia \& Lu, 2016, pp. 1-11).

Obviously, each country has the opportunity to develop its own health care management system, although similar historical conditions and health policy goals caused that these systems have some common features (Kujawska, 2015, p. 113). Despite those similarities, particular countries responded differently to external shocks, including the financial crisis that affected health care spending. These shocks were therefore asymmetrical. Some countries also used the crisis to reduce their spending level, for example through its absolute reduction (Cyprus, Greece, Ireland, Lithuania, Portugal, Romania) or freezing salaries of healthcare workers (Great Britain, Slovenia) or lowering salaries (e.g. Denmark) (Karanikolos, Mladovsky et al., pp. 1323-1331). The adopted study interval took into account the period of crisis that could have had an impact on disparities in health care expenditure. In the analysed group of countries in the time period from 2004 to 2015, the expenditure on health care was clearly differentiated. Relatively low values were observed in Luxembourg, in Poland and the Czech Republic, while the highest level of expenditure was observed in Denmark.

\section{METHODOLOGY - SIGMA AND BETA ANALYSIS AND UNCONDITIONAL CONVERGENCE}

The aim of the study is to investigate the phenomenon of sigma and beta unconditional (absolute) convergence of the level of government spending on healthcare for the EU12 (Old EU) and Visegrad Group (V4) countries. For this purpose, two analyses were conducted - sigma and beta convergence for 16 countries in the period 2002-2015. The research material came from the Eurostat database. GRETL 2016d program was used for the estimation of regression parameters.

Discussing the convergence considerations, a number of methods must be taken into account to confirm its existence. In the literature we can find different methods of measurement, including sigma $(\sigma)$, beta $(\beta)$ and gamma $(\gamma)$ convergence (Kusideł, 2013, pp. 46-71). Still, two main concepts are the sigma and beta analyses, which most often appear in classical literature (Sala-i-Martin, 1995, p. 3). Considering the accepted purpose of the paper, the authors analysed the convergence of health expenditure using the sigma convergence analysis and the beat unconditional (absolute) convergence. For this purpose, Eurostat 
databases were used and decomposition of total government expenditure on individual sub-spending was made, on the basis of which both analyses were carried out. Such an approach to obtaining particular state spending was also widely used in a number of studies, for example, selected components of government spending on consumption were examined by Dada (2013, pp. 22-28) by initially disaggregating total government expenditure for government administration expenditure, education, health, agriculture, construction, public transport and communications, and government spending on social security. Conducting the sigma convergence analysis, a standard deviation of the logarithm of natural government expenditures on health care was used. The analysed equation for each time unit tadopted the form (Malaga, 2004, p. 57)1:

$$
\sigma=\sqrt{\sum_{i=1}^{n}\left(\ln H E_{i t}-\ln \overline{H E_{t}}\right)^{2}}
$$

where:

$i$ - country index,

$\mathrm{HE}_{\mathrm{it}}$ - the level of government spending on health care in the country $i$ and at time $t$,

$\overline{H E_{t}}$ - the average level of government spending on health care in the considered group of countries.

When there is a decrease in the dispersion of the examined feature over time, we refer to the occurrence of sigma convergence (table 1). It is also convenient to determine the rate of change of the sigma parameter under study or to make a visual analysis of the distribution of sigma convergence points in the graph. It is also permitted to apply the following regression equation (Jóźwik, 2014, p. 99):

$$
\sigma_{t}=\alpha_{0}+\alpha_{1} t
$$

where:

$\sigma_{t}$-standard deviation of the natural logarithm of the examined feature between countries at time $t$.

${ }^{1}$ In the work of K. Malaga, different signs of variables were used in view of the different subject of the study. 
In such an estimated function, the negative parameter at $\alpha_{1}$ signals sigma convergence occurrence (table 2).

The second common measure of convergence is beta convergence. We can distinguish beta absolute (unconditional) convergence and beta conditional convergence. Beta absolute convergence occurs when poorer economies develop faster than the richer ones (Sala-i-Martin, 1995, p. 3). In the case under consideration, countries with lower levels of health expenditures increase them faster than those with relatively high levels of health expenditure. Then the different countries are striving for the same steady state of long-term equilibrium. We assume that all economies, at the same percentage, reduce the distance to long-term equilibrium and at the same time reach that state. In turn, the conditional convergence beta analyses the phenomenon when a country's economy converges to its own steady-state equilibrium (Malaga, 2004, p. 66). The coefficient $\beta$ indicates the percentage of distance to the long-term equilibrium of the economy over one period (Próchniak \& Rapacki, 2007, p. 44). The application of $\beta$-absolute analysis allows to examine the convergence of health expenditure in the analysed group of states. For this purpose, an estimate of the regression equation is required (Próchniak, 2006, p.75)²:

$$
\frac{1}{T} \ln \frac{H E_{r}}{H E_{0}}=\alpha_{0}+\alpha_{1} \ln H E_{0}
$$

where:

$\mathrm{HE}_{\mathrm{r}}$ - level of expenditure on health in the final period,

$\mathrm{HE}_{0}$ - level of expenditure on health in the end period.

If the value of $\alpha_{1}$ is negative, the value of parameter $\beta$ can be calculated from the formula:

$$
\beta=-\frac{1}{T} \ln \left(1+\alpha_{1} T\right)
$$

It should also be noted that $\beta$ convergence is a necessary but not sufficient condition for the occurrence of $\sigma$-type convergence. This may be the case when the less developed economies (or the relative weakness of the surveyed feature) will develop rapidly enough to surpass the more developed economy

2 In the work of M. Próchniak, the original variant of the variables is different from the ones accepted by the authors due to another subject of the study. 
(Próchniak, 2006, p. 75). This is related to the paradox of Galton, which consists in the simultaneous occurrence of $\beta$ convergence and the lack of convergence $\sigma$ (Głodowska, 2012, p. 181).

\section{RESULTS}

In the analysed time range for the $12 \mathrm{EU}$ countries and the V4 group, there is a clear divergence of health care expenditure. In the period in study there was a continuous increase in the divergence of the examined feature (table 1). The same conclusions can be drawn by analysing a regression equation, in which the parameter $\alpha_{1}$ has a statistically significant higher value than zero. Consequently, individual countries, although operating within one integration group, did not show one path of adjustment to public health spending. This process has been systematically increasing disproportion over time since 2005, due to the substantial enlargement of the EU by 10 new countries. This can be represented as a time-dependent regression function (table 2).

Table 1. Measuring the sigma convergence of health care spending in the EU12 states and V4 group

\begin{tabular}{|c|c|c|}
\hline \hline Research period & Sigma convergence & Change rate \\
\hline \hline 2002 & 0.568314 & 1.021469 \\
\hline 2003 & 0.580515 & 1.032335 \\
\hline 2004 & 0.599286 & 0.866315 \\
\hline 2005 & 0.51917 & 1.017528 \\
\hline 2006 & 0.52827 & 1.178301 \\
\hline 2007 & 0.622461 & 1.001485 \\
\hline 2008 & 0.623386 & 1.063161 \\
\hline 2009 & 0.662759 & 1.021086 \\
\hline 2010 & 0.676734 & 1.045153 \\
\hline 2011 & 0.70729 & 1.048565 \\
\hline 2012 & 0.74164 & 1.014466 \\
\hline 2013 & 0.752369 & 1.097306 \\
\hline 2014 & 0.825579 & 0.977913 \\
\hline \hline
\end{tabular}

S o u r c e : own study on Eurostat data. 
Table 2. Regression function for sigma analysis

\begin{tabular}{|l|c|c|c|c|c|}
\hline \hline & Coefficient & Standard error & t-Student & $\boldsymbol{p}$ value & R2 \\
\hline \hline Const & 0.4961 & 0.0223719 & 22.1751 & $<0.0001^{* * *}$ & \multirow{2}{*}{0.849408} \\
\cline { 1 - 5 } Time & 0.0216163 & 0.00262745 & 8.2271 & $<0.0001^{* * *}$ & \\
\hline \hline
\end{tabular}

S o u r c e : own study based on Eurostat data using GRETL 2016d program.

Table 3. Measurement of beta absolute convergence for health expenditure in EU12 states and V4 group

\begin{tabular}{|c|c|c|c|c|c|c|c|c|}
\hline \multirow{2}{*}{$\begin{array}{l}\text { Research } \\
\text { period }\end{array}$} & \multicolumn{8}{|c|}{ Estimated values } \\
\hline & $\alpha 0$ & $\alpha 1$ & $\mathrm{~T} \alpha 0$ & $\mathrm{~T} \alpha 1$ & $p \alpha 0$ & $p \alpha 1$ & $\mathbf{R} 2$ & $\beta$ \\
\hline 2002-2006 & 0.078036 & -0.0369546 & 1.811 & -1.526 & $0.0916^{*}$ & 0.1493 & 0.142587 & 0.040858 \\
\hline 2002-2007 & 0.030116 & -0.0124092 & 0.6959 & -0.5101 & 0.4979 & 0.6179 & 0.018247 & 0.012895 \\
\hline 2002-2008 & 0.054976 & -0.0234355 & 1.2491 & -0.9472 & 0.2321 & 0.3596 & 0.060225 & 0.025598 \\
\hline 2002-2009 & 0.058022 & -0.0198219 & 1.3361 & -0.812 & 0.2028 & 0.4304 & 0.044973 & 0.021582 \\
\hline 2002-2010 & 0.045125 & -0.0151188 & 1.1424 & -0.6809 & 0.2724 & 0.5071 & 0.032053 & 0.016251 \\
\hline 2002-2011 & 0.029286 & -0.00851732 & 0.7935 & -0.4105 & 0.4408 & 0.6877 & 0.011892 & 0.008902 \\
\hline 2002-2012 & 0.027027 & -0.0080678 & 0.7178 & -0.3812 & 0.4847 & 0.7088 & 0.010272 & 0.008448 \\
\hline 2002-2013 & 0.031181 & -0.0114644 & 0.8302 & -0.543 & 0.4203 & 0.5957 & 0.020626 & 0.012334 \\
\hline 2002-2014 & 0.019065 & -0.00554119 & 0.4891 & -0.2529 & 0.6324 & 0.8041 & 0.004546 & 0.005751 \\
\hline 2002-2015 & 0.023336 & -0.00909286 & 0.6334 & -0.439 & 0.5367 & 0.6673 & 0.01358 & 0.009726 \\
\hline
\end{tabular}

S o u r c e : own study based on Eurostat data using GRETL 2016d program.

In the analysed time series, in each case the value of $\beta$ parameter was positive, which would indicate a convergence of health care expenditure. It should be noted, however, that none of the structural parameters of the model reached satisfactory statistical significance, and the coefficient $\mathrm{R}^{2}$ in each case is low. The significance indicator of the initial income level of p $\alpha 1$ is only low for the initial period and amounts to $14.93 \%$, but for this period it is unsatisfactory (the variable can be considered significant if the index does not exceed $10 \%$ (Próchniak \& Rapacki, 2007, p. 49)). For subsequent periods it is much higher (for the latter it is $66.73 \%$ ). Also in this case, positive values of the $\beta$ parameter should be carefully evaluated, especially with such unambiguous divergence 
results in the $\sigma$ analysis. This does not allow for the unambiguous occurrence of beta convergence.

\section{CONCLUSION}

The analysis of public health expenditure has shown a varied course of these paths over time. Due to the differences between the social and family structures as well as the specific characteristics of welfare states, convergence in the expenditure group under consideration cannot be stated. The conducted sigma convergence analysis negated the existence of health care spending fluctuations for EU12 and V4 countries. The assessment of this convergence is indicative of a reversal phenomenon - divergence. There was disagreement in the assessment between beta and sigma convergence (although in the first case the necessary significance was not achieved). It seems that in the case of this second convergence, weaknesses in this approach arose, indicating that the relationship between the rate of change in health care expenditure and its initial level does not imply a reduction in the dispersion structure and there may even occur a reverse phenomenonin the presence of a positive $\beta$ value. This is due to the high variability between countries in the rate of change (effect of extreme magnitude). On the other hand, sigma divergence was identified, and therefore the increase in discrepancies over time. This may indicate the phenomenon of polarization of these expenses within the EU states.

\section{REFERENCES}

Czyżewski, A., \& Kułyk, P. (2009). Konwergencja czy dywergencja mechanizmów wsparcia sektora rolnego? Zeszyty Naukowe SGGW w Warszawie - Problemy Rolnictwa Światowego, t. 8(23).

Dada, M.A. (2013). Composition Effects of Government Expenditure on Private Consumption and Output Growth in Nigeria: a Single-Equation Error Correction Modelling. Romanian Journal of Fiscal Policy, Volume 4, Issue 2(7).

Głodowska, A. (2012). Znaczenie konwergencji w aktualnej i przyszłej polityce strukturalnej Unii Europejskiej. Nierówności Społeczne a Wzrost Gospodarczy, nr 24.

Hitiris, T. (1997). Health care expenditure and integration in the countries of the European Union. Applied Economics, 29(1).

Hnatyszyn-Dzikowska, A., \&Wyszkowska,Z. (2015). Konwergencja wydatków na opiekę zdrowotną w państwach Unii Europejskiej - zarys problematyki. Nierówności Społeczne a Wzrost Gospodarczy, nr 43. http://dx.doi.org/10.15584/nsawg.2015.3.10.

http://appsso.eurostat.ec.europa.eu/nui/submitViewTableAction.do (accessed: 10.05.2017). 
Jóźwik, B. (2014). Konwergencja gospodarcza w regionach państw członkowskich Unii Europejskiej z Europy Środkowo-Wschodniej. Roczniki Ekonomii i Zarządzania, Tom 6(42).

Karanikolos, M., Mladovsky, P., Cylus J., Thomson, S., Basu, S., Stuckler, D., Mackenbach, J. P., \& McKee, M. (2013). Financial crisis, austerity, and health in Europe. The Lancet, 383(9874), http://dx.doi.org/10.1016/S0140-6736(13)60102-6.

Kerem, K., Püss, T., Viies, M., \& Maldre, R. (2008). Health And Convergence Of Health Care Expenditure In EU. International Business \& Economics Research Journal, 7(3).

Kujawska, J. (2015). Porównanie funkcjonowania systemów opieki zdrowotnej w europejskich krajach OECD. Problemy Zarządzania, vol. 13, nr 2 (53), t. 2. http:// dx.doi.org/10.7172/1644-9584.53.7.

Kułyk, P., Augustowski, Ł. (2016), Analiza konwergencji wydatków rządowych w wybranych państwach strefy euro i Polski w latach 1995-2015, [w:] K. Opolski, J. Górski (red.), Wyzwania integracji gospodarczej w Unii Europejskiej, Wydział Nauk Ekonomicznych Uniwersytetu Warszawskiego, Warszawa.

Kusideł, E. (2013), Konwergencja gospodarcza w Polsce i jej znaczenie w osiąganiu celów polityki spójności, Wydawnictwo Uniwersytetu Łódzkiego, Łódź.

Lau, C.K., Fung, K. W., \& Pugalis, L. (2014). Is healthcare expenditure across Europe converging? Findings from the application of a nonlinear panel unit root test. Eurasian Business Review, 4(2). http://dx.doi.org/ 10.1007/s40821-014-0014-9.

Malaga, K. (2004), Konwergencja gospodarcza w krajach OECD w latach 1960-1999. Wyniki badań empirycznych, [w:] E. Panek, Matematyka w ekonomii, Wydawnictwo Akademii Ekonomicznej w Poznaniu, Zeszyt 41.

Nixon, J. (1999). Convergence Analysis of Health Care Expenditure in the EU Countries Using Two Approaches. Department of Economics and Related Studies, University of York, Heslington, Discussion Papers in Economics, No 1999/03.

Nixon, J. (2000). Convergence of Health Care Spending and Health Outcomes in the European Union, 1960-95. Centre for Health Economics, Discussion Paper: The University of York, No. 183.

Odhiambo, S. A., Wambugu A., \& Kiriti-Ng'ang'a, T. (2015). Convergence of Health Expenditure in Sub-Saharan Africa: Evidence from a Dynamic Panel. Journal of Economics and Sustainable Development, 6(6).

Panopoulou, E., \& Pantelidis, T. (2012). Convergence in Per Capita Health Expenditures and Health Outcomes in the OECD Countries. Applied Economics, Volume 44. http:// dx.doi.org/10.1080/00036846.2011.583222.

Próchniak, M. (2006). Realna konwergencja typu beta $(\beta)$ i sigma ( $\sigma$ ) w świetle badań empirycznych. Zeszyty Naukowe SGH, nr 20.

Próchniak, M., \& Rapacki, R. (2007). Konwergencja beta i sigma w krajach postsocjalistycznych w latach 1990-2005. Bank i Kredyt, nr 8-9.

Sala-i-Martin, X. (1996). The Classical Approach to Convergence Analysis. Economic Journal, 106(437).

Strzelecka, A. (2011). Konwergencja wydatków na opiekę zdrowotną w wybranych krajach w latach 1990-2008. Acta Universitatis Nicolai Copernici, Ekonomia XLII Nauki humanistyczno-społeczne, Zeszyt 402. 
Wan, G. H. (2005). Convergence in Food Consumption in Rural China: Evidence from Household Survey Data. China Economic Review, 16(1). http://dx.doi.org/10.1016/j. chieco.2004.09.002.

Zaidi, A., Gasior, K., Zolyomi, E., Schmidt, A., Rodrigues, R., \& Marin, B. (2017). Measuring active and healthy ageing in Europe. Journal of European Social Policy, 27(2). http://dx.doi.org/10.1177/0958928716676550.

Zhang, G., Zhang, L., Wu, S., Xia, X., \& Lu, L. (2016). The convergence of Chinese county government health expenditures: capitation and contribution. BMC Health Services Research. http://dx.doi.org/10.1186/s12913-016-1635-8. 
